\title{
Customer Satisfaction Of Greek Mobile PHONE SERVICES
}

\author{
Stergios Vranakis ${ }^{1}$, Prodromos Chatzoglou ${ }^{2}$, and Apostolos Mpaloukas ${ }^{3}$ \\ ${ }^{1}$ Production \& Management Engineering Department, Democritus University of Thrace, \\ Xanthi, Greece \\ stergiosevranakis.gr \\ ${ }^{2}$ Production \& Management Engineering Department, Democritus University of Thrace, \\ Xanthi, Greece \\ pchatzog@pme.duth.gr \\ ${ }^{3}$ Production \& Management Engineering Department, Democritus University of Thrace, \\ Xanthi, Greece \\ apostolis_mpaloukasehotmail.com
}

\begin{abstract}
The mobile telephony market is one of the fastest-growing segments in the global economy. The competition in this sector has become very intense and the companies' need for survival, in these very difficult conditions that dominate in this sector, force them to search for ways to attract and retent customers. The main condition for the maintenance of their brand life, in the long term, is to win customers' loyalty. Customer satisfaction consists a basic factor for achieving this aim.

The objectives of this research, is to capture the present situation with regard to the satisfaction of Greek users of mobile phone services. The research model that has been developed incorporates many factors that influence customers' satisfaction. Structured questionnaires from mobile phone services users are collected to test the research model.The results indicate that company image is the main factor affecting not only customer satisfaction, but also perceived value, service quality and customer loyalty.
\end{abstract}

\section{KEYWORDS}

Customer Satisfaction, Mobile Phone Services, Customer Loyalty, Company Image

\section{INTRODUCTION}

The enormous competition in the area of mobile telephony services (MTS) has forced companies that are active in this field to find ways to cope with the great demands of the market and to increase their market share (Rust \& Zahorik, 1993). For these enterprises, the increase in customer satisfaction is a fundamental goal, while their utter purpose is to enforce the customer loyalty to the company and to maintain long-term customer relationships (Kotler, 1982).

The purpose of the present survey is (a) the understanding of the importance of consumer satisfaction and its effect on the efficiency of a company, (b) the creation of an improved model for measuring consumers' satisfaction of MTS companies in the Greek market, and (c) to draw some useful conclusions for the most important factors and the way they affect the level of satisfaction of the consumers of the MTS providers in Greece.

\subsection{Development of mobile telephony in Greece}

Mobile telephony networks started their operations worldwide during the 1980s. They reach their peak in the early 90s with the introduction of the digital cellular systems. In Europe, the introduction of the pan - European digital system (GSM) had a vast contribution to the impressive spread of the mobile telephony. 
The penetration of mobile telephony in Greece in the end of 2004 was estimated to $101 \%$ of the Greek population (Grigoroudis \& Siskos, 2004). Mobile telephony appears to have faster growth rates than the conventional telephony market, which results in the increase of the mobile telephony revenues.

With the liberalisation of the market, the entrance of several companies providing telephony services, both conventional and cellular, an intense competition, focusing on prices, has emerged this fact, along with the rapid advancement that the communication technologies has brought, contributed to the constant reduction of the prices of telephony services (Athanassopoulos, 2000).

The main target of all the companies in the telecommunication industry in Greece was the dominance over the mobile telephony market, with first place changing hands many times. Today, while Cosmote is first, as far as the number of contract subscribers is concerned, Vodafone is first considering the number of prepaid telephone subscribers (Grigoroudis \& Siskos, 2004).

\section{LITERATURE REVIEW}

Companies' need for survival forces them to find ways to preserve and to augment the market share they possess. It is essential for a company to keep its customers satisfied, because it is far more expensive for a company to attract new customers than to maintain the ones it already has (Kotler, 1982). Previous studies have proven the importance of consumer satisfaction and its effects on both the maintenance of customers and the efficiency of a company (Rust \& Zahorik, 1993). The first step for managing customer satisfaction is the understanding of what the customers really want.

Customer satisfaction has been the center of the research for some time in the area of consumer's psychology. Yi (1991) summarised some of literature's definitions in customer satisfaction. Consumer satisfaction has been defined as "the evaluation that the consumer experience is at least as good as it is supposed to be" (Hunt, 1977: 4591), or as "an evaluation where the chosen alternative choice is in agreement with the prior beliefs and always keeping in mind this alternative " (Engel \& Blackwell, 1982: 5011), and also as "the response of the consumer to the evaluation of the perceived differences between the prior beliefs (or a performance pattern) and the actual performance of the product, the way it is perceived after its consumption" (Tse \& Wilton, 1988: 2041). A recent and more concise definition is given by Oliver (1997), who defines satisfaction as the "response to consumer fulfilment".

Customer satisfaction is also defined as a result that comes from the pre - purchasing customer comparison among the expected performance, the perceived actual performance and the existing cost (Churchill \& Surprenant, 1982). Literature supports that customer satisfaction acts in two different ways: the satisfaction of a certain transaction and the overall satisfaction (Yi, 1991).

Generally, the level of satisfaction indicates to what extent customers are satisfied and to what degree their expectations have been confirmed. In this research, this factor evaluates the level of the total customer satisfaction, the fulfilment of their expectations and the efficiency of the company in comparison with the ideal (Turkyilmaz \& Ozkan, 2007).

\subsection{Factors that affect customer satisfaction}

Many and different models of customer satisfaction have been proposed since the beginning of 1970, mainly due to the difference in interpretation of the word satisfaction by a number of researchers. Erevalles \& Leavit (1992) conducted a review and gathered the characteristics from most of the customer satisfaction models that had been developed in the 1980s.

Company image is defined as the total impression that the public has for a company (Barich \& Kotler,1991; Dichter, 1985; Finn, 1961; Kotler, 1982). From the companies' perspective, being reliable, professional and innovative, having social contribution and valuing the customers are 
the elements that form the company image. Martensen et al. (2000) indicate that the image is an important element in the customer satisfaction model. The image is expected to have a positive relationship towards the customer expectations, customer satisfaction and loyalty of customers to the company.

Customer loyalty has been defined as a longterm commitment for the consumer to remain in the same company, and use more products and services in the future (Dick \& Basu, 1994; Flavian $\&$ Guinaliu, 2006). Company image and customer satisfaction are found to affect positively customers' loyalty (Anderson \& Fornell, 2000).

Signal quality and network coverage have always been essential criteria for selecting MTS providers. During the previous years, where technology had not advanced so much in this area, company networks were limited only to certain locations. Today the signal quality has been improved and the company networks have grown to a great extent. Surveys have shown that both signal quality and network coverage affect positively consumer's satisfaction and the image of the company (Woo et al., 1999).

Perceived value is defined as the perceived quality level of a product, compared to the price that a customer pays to acquire it (Fornell et al., 1996). As some researchers have concluded (Day, 1990; Narver and Slater, 1990), the creation of high perceived value is the main target of the market-driven companies. Perceived value provides a comparison measure to the companies in proportion to the price - value ratio (Anderson et al., 1994a).

In the past years, various researches have been conducted on different aspects related to service quality. Traditionally, the quality of services is defined as the difference between the expectations of the customer and the perception of services (Gronroos, 1984; Parasuraman et al., 1988, 1991).

MTS providing companies consider the area of customer service as very important. A proof for the above statement is the continuous expantantion of their customer service departments. Customers however, apart from customer service departments, want to have constant communication with the people from other departments within the company. For this reason, all companies are providing free communication with almost all their departments.

The selection of appropriate and qualified personnel is considered to be an essential issue for these companies. Customers in order to be satisfied from a transaction, in addition to the quality of the product and the low price, are also interested in being treated well from the personnel.

The strategic importance of managing customers' complaints was examined for the first time by Fornell \& Westbrook (1984). They showed that by encouraging the expression of customer complaints today, a company might be able to decrease future complaints. It is very important for any customer to know where he can address his complaints which will be given the proper consideration.

\section{RESEARCH MODEL}

Through this survey, an effort is made to study the role of consumers' satisfaction in the area of MTS and its influence on the efficiency of companies. The model incorporates many of the research conclusions and views of other researchers who have been studying similar subjects in other fields or/and in other countries. Their views are various and diverse, and for this reason the proposed research model (Figure 1) includes many factors that affect consumer satisfaction and lead to increased customer loyalty.

The hypotheses that will be tested in this research are the following:

Hypothesis 1: Perceived value has a positive effect on customer satisfaction.

Hypothesis 2: Service quality affects positively:

a) perceived value, and 
b) customer satisfaction.

Hypothesis 3: Signal and network coverage affects positively:

a) service quality, and

b) customer satisfaction.

Hypothesis 4: Company image affects positively:

a) customer devotion,

b) perceived value,

c) customer satisfaction, and

d) service quality.

Hypothesis 5: Customer satisfaction has a positive effect on customer loyalty.

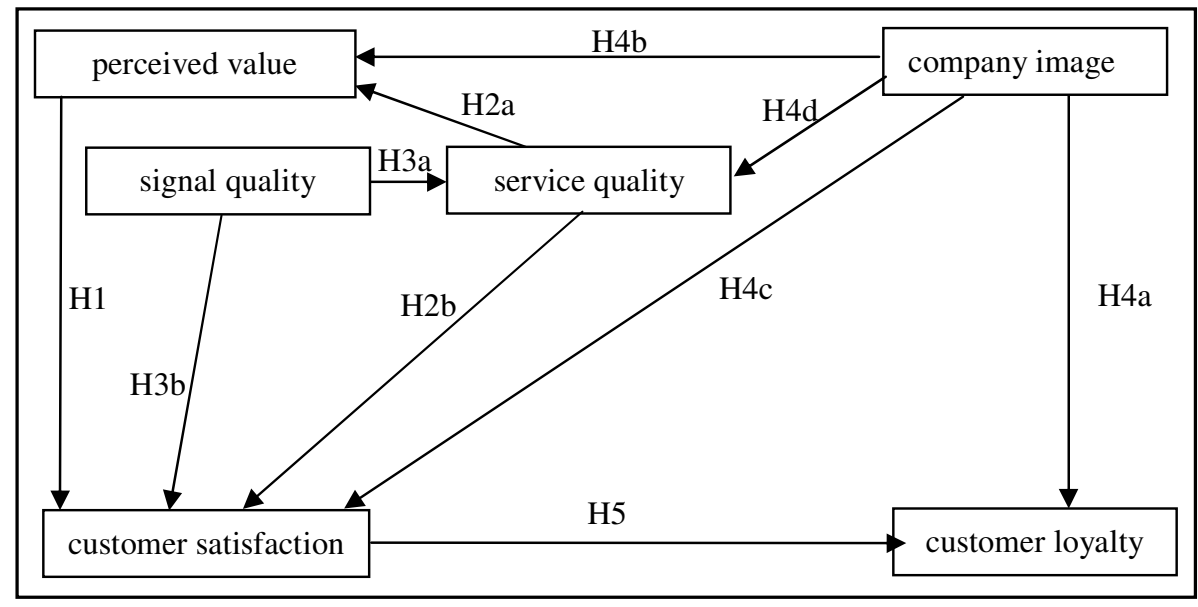

Figure 1: Research model

\section{RESEARCH METHODOLOGY}

The research was limited to MTS providers that operate in Greece. Through this survey, an attempt has been made to discover to what extent customers of MTS are satisfied by the services offered to them. The questions were chosen so that answers would be given to all the factors that may affect consumers' satisfaction from MTS according to the research model. The questionnaire was consisted of 48 questions and was divided in 9 sections. The Likert scale measurement was used for all the questions (1="strongly agree" and 7="strongly disagree").

\section{ANALYSIS AND INTERPRETATION OF THE RESULTS}

\subsection{Frequency Analysis}

The first category of question in the survey questionnaire contains general information about the respondents and the MTS company they use. In the present survey $50.7 \%$ of the questionnaires were answered by men, while the remaining $49.3 \%$ by women. The age of the majority of the respondents ranges from 18 to 25 years and represents $38.3 \%$ of the total number of respondents. As far as the education level is concerned, most of the respondents are high school graduates (40\%), while another 36.3\% holds a university degree. Moreover, $61.7 \%$ of the research participants have a contract with the company, while $39.3 \%$ have a prepaid connection package.

Considering the signal quality and network coverage of the company that every respondent uses, it was found that the respondents are generally satisfied. Certainly, the satisfaction from the network coverage outdoors is slightly higher (average $=2.31$ ) than the satisfaction from the network coverage indoors (average $=2.47$ ). Furthermore, the respondents are satisfied from the transmission quality of the signal (average $=2.55$ ). 
As far as the perceived value from the customer's point of view is concerned, it was found that they are neither satisfied nor dissatisfied. Specifically, looking at the price of the service packages as well as the quality of the provided services the average response was found to be around the middle point (average 3.18 and 3.44 respectively).

In regards to customer service, the results are rather positive, given that the companies are moving to the right direction and satisfy their customers. Particularly, customers respond that the bills sent to them from the MTS company are precise, undoubted and with fully understandable data (average=2.36). Examining customers' satisfaction from the repair and maintenance services that the customer service departments offers, it is found that although the results show a disposition in favour of satisfaction, it is clear that customers want more and even better services (average $=3.02$ ). An explanation for this result could be provided by the fact that only in a limited number of cases customer service departments can respond immediately to customer's demands, while in most of the cases they send the products to be repaired at their headquarters.

The results also reveal that MTS providers pay great attention to the selection of personnel for their offices/shops, as well as to the constant supply of services. The responses concerning the supply of constant services indicate that customers are relatively satisfied (average $=2.34$ ). Similar results occur when the satisfaction from the willingness of the personnel (average $=2.45$ ) and the satisfaction from the personnel's ability to resolve a given problem (average $=2.76$ ) are examined. Thus, it is clear that companies have put great emphasis on these areas and by doing so they have succeeded to increase the level of customers' satisfaction.

Further, evaluating the results concerning customer complaints, it is obvious that there is a customers' tendency to express their dislike, officially or unofficially, when they believe that the services and products companies offer them do not meet their expectations (average=3.12). The frequency of these complaints in many cases is high (average $=2.45$ ). Yet, customers claim that there is a difficulty to find where they should address their complaints (average=3.01).

The next category of questions refers to customer loyalty (devotion). It is very obvious that customers have the intention to remain customers of the same company (average=2.35). As regards to whether the respondents have proposed the company they use to others and their satisfaction from the company's pricing policy, the replies were found to be around the middle point (average 3.57 and 3.53 respectively). The conclusion that could be drawn from these results is that the customers are, generally, devoted to their companies. As far as the image of the company is concerned, respondents consider the company they use to be reliable (average $=2.19$ ) and professional (average $=2.26$ ). Considering its social contribution, the results were not as positive as the previous ones (average $=3.07$ ). Satisfactory enough were the replies about whether the company keeps good relations with the customers (average $=2.62$ ). The creation of the company image, which is often related to symbols and values, is a continuous process that can be improved fast with some technological achievements, or, on the contrary, be destroyed if the needs and expectations of various users related to the company were to be disregarded (Dichter, 1985; Herbig et al., 1994).

Finally, examining the questions referring to the level of the total customers' satisfaction from their companies, it is revealed that for the majority of the questions the results were positive (average $=2.68$ ). Yet, the mean of the question referring to quality of the services provided by the company provides approach the ideal level is relatively low (average=3.54), and this should be food for thought for these companies.

\subsection{Factor Analysis}

Factor analysis was initially used to examine the research model that was presented in Figure 2. The results are presented in Table 1. The indicators that are being examined for the evaluation 
International Journal of Managing Value and Supply Chains (IJMVSC) Vol. 3, No. 4, December 2012

of the results are: (i) Kaiser-Meyer-Olkin (K.M.O.), (ii) Bartlett's test of sphericity, (iii) Total Variance Explained (TVE) and (iv) the loadings of every variable in the factor that it belongs.

\begin{tabular}{|c|c|c|c|c|c|}
\hline Factors & Statistics & Variables & Mean & $\begin{array}{l}\text { Standard } \\
\text { Deviation } \\
\end{array}$ & Loadings \\
\hline \multirow{3}{*}{$\begin{array}{l}\text { Signal } \\
\text { quality \& } \\
\text { network } \\
\text { coverage }\end{array}$} & \multirow{3}{*}{$\begin{array}{c}\text { K.M.O.= 0.720 } \\
\text { Bartlett's Sig = } \\
0.00 \\
(\text { TVE) }=76.458 \\
\text { Cronbach }(\mathrm{a})= \\
0.844 \\
\end{array}$} & $\begin{array}{l}\text { Network coverage is } \\
\text { satisfactory indoors. }\end{array}$ & 2.47 & 1.591 & 0.847 \\
\hline & & $\begin{array}{l}\text { Network coverage is } \\
\text { satisfactory outdoors. }\end{array}$ & 2.31 & 1.459 & 0.893 \\
\hline & & $\begin{array}{l}\text { Transmission quality of } \\
\text { signal is satisfactory. }\end{array}$ & 2.55 & 1.445 & 0.883 \\
\hline \multirow{4}{*}{$\begin{array}{l}\text { Perceived } \\
\text { value }\end{array}$} & \multirow{4}{*}{$\begin{array}{c}\text { K.M.O.=0.756 } \\
\text { Bartlett's Sig = } \\
0.00 \\
\text { (TVE) }=64.752 \\
\text { Cronbach (a) } \\
=0.818\end{array}$} & $\begin{array}{l}\text { There is a big variety of } \\
\text { packet services. }\end{array}$ & 2.65 & 1.513 & 0.777 \\
\hline & & $\begin{array}{l}\text { The cost of packet } \\
\text { services is satisfactory. }\end{array}$ & 3.18 & 1.660 & 0.809 \\
\hline & & $\begin{array}{l}\text { The cost of mobile is } \\
\text { satisfactory. }\end{array}$ & 3.55 & 1.717 & 0.793 \\
\hline & & $\begin{array}{l}\text { Rating of price has } \\
\text { given quality }\end{array}$ & 3.44 & 1.715 & 0.838 \\
\hline \multirow{5}{*}{$\begin{array}{l}\text { Customer } \\
\text { service }\end{array}$} & \multirow{5}{*}{$\begin{array}{c}\text { K.M.O.= } 0.829 \\
\text { Bartlett's Sig = } \\
0.00 \\
\text { (TVE) }=63.660 \\
\text { Cronbach (a) } \\
=0.854\end{array}$} & $\begin{array}{l}\text { My bills are sent are } \\
\text { printed with accuracy, } \\
\text { clarity and full data } \\
\text { information. }\end{array}$ & 2.36 & 1.674 & 0.730 \\
\hline & & $\begin{array}{l}\text { The service centers' } \\
\text { locationsí } \varsigma \text { are easily to } \\
\text { be found. }\end{array}$ & 2.30 & 1.437 & 0.836 \\
\hline & & $\begin{array}{l}\text { I'm satisfied by the } \\
\text { working hours of } \\
\text { service centers. }\end{array}$ & 2.48 & 1.623 & 0.818 \\
\hline & & $\begin{array}{l}\text { I'm satisfied by the } \\
\text { product maintenance of } \\
\text { the service centers. }\end{array}$ & 3.02 & 1.676 & 0.803 \\
\hline & & $\begin{array}{l}\text { The communication } \\
\text { with the company is } \\
\text { satisfactory. }\end{array}$ & 2.81 & 1.748 & 0.798 \\
\hline \multirow{3}{*}{$\begin{array}{l}\text { Selection of } \\
\text { personell } \\
\text { for their } \\
\text { establishme } \\
\text { nt }\end{array}$} & \multirow{3}{*}{$\begin{array}{c}\text { K.M.O.= } 0.738 \\
\text { Bartlett's Sig = } \\
0.00 \\
\text { (TVE) }=81.172 \\
\text { Cronbach (a) } \\
=0.880\end{array}$} & $\begin{array}{l}\text { The service is } \\
\text { continuous. }\end{array}$ & 2.34 & 1.353 & 0.880 \\
\hline & & $\begin{array}{l}\text { Company's personell is } \\
\text { eager. }\end{array}$ & 2.45 & 1.537 & 0.916 \\
\hline & & $\begin{array}{l}\text { The company put } \\
\text { efforts to solve } \\
\text { customer's } \\
\text { inconvenience }\end{array}$ & 2.76 & 1.736 & 0.906 \\
\hline \multirow{3}{*}{$\begin{array}{l}\text { Customer } \\
\text { complaints }\end{array}$} & \multirow{3}{*}{$\begin{array}{c}\text { K.M.O.= } 0.579 \\
\text { Bartlett's Sig = } \\
0.00 \\
\text { (TVE) }=58.924 \\
\text { Cronbach (a) } \\
=0.629\end{array}$} & $\begin{array}{l}\text { Had the customer } \\
\text { complained either } \\
\text { formally or informally } \\
\text { about the product or } \\
\text { service. }\end{array}$ & 3.12 & 2.095 & 0.793 \\
\hline & & $\begin{array}{l}\text { My complaints are } \\
\text { frequent. }\end{array}$ & 2.45 & 1.618 & 0.859 \\
\hline & & $\begin{array}{l}\text { Was hard for me to find } \\
\text { where to complain. }\end{array}$ & 3.01 & 1.932 & 0.633 \\
\hline
\end{tabular}


International Journal of Managing Value and Supply Chains (IJMVSC) Vol. 3, No. 4, December 2012

\begin{tabular}{|c|c|c|c|c|c|}
\hline \multirow{5}{*}{$\begin{array}{l}\text { Customer } \\
\text { loyalty }\end{array}$} & \multirow{5}{*}{$\begin{array}{c}\text { K.M.O.= } 0.815 \\
\text { Bartlett's Sig = } \\
0.00 \\
\text { (TVE) }=56.013 \\
\text { Cronbach (a) } \\
=0.800\end{array}$} & $\begin{array}{l}\text { I have no intention not } \\
\text { to leave the specific } \\
\text { company. }\end{array}$ & 2.35 & 1.481 & 0.730 \\
\hline & & $\begin{array}{l}\text { I have suggested the } \\
\text { company I use. }\end{array}$ & 3.53 & 2.143 & 0.816 \\
\hline & & $\begin{array}{l}\text { I'm satisfied by the } \\
\text { pricing policy. }\end{array}$ & 3.57 & 1.884 & 0.811 \\
\hline & & $\begin{array}{l}\text { Intented to use much } \\
\text { more services. }\end{array}$ & 4.14 & 1.925 & 0.682 \\
\hline & & $\begin{array}{l}\text { The contents company } \\
\text { controlled the private } \\
\text { and information and } \\
\text { transaction data well. }\end{array}$ & 3.10 & 1.700 & 0.691 \\
\hline \multirow{6}{*}{$\begin{array}{l}\text { Company } \\
\text { image }\end{array}$} & \multirow{6}{*}{$\begin{array}{c}\text { K.M.O.= 0.841 } \\
\text { Bartlett's Sig = } \\
0.00 \\
(\text { TVE) }=65.428 \\
\text { Cronbach (a) } \\
=0.891\end{array}$} & Being reliable. & 2.19 & 1.403 & 0.711 \\
\hline & & Being professional. & 2.26 & 1.359 & 0.820 \\
\hline & & $\begin{array}{l}\text { Social contributions to } \\
\text { society. }\end{array}$ & 3.07 & 1.781 & 0.763 \\
\hline & & Customer relations. & 2.62 & 1.563 & 0.852 \\
\hline & & $\begin{array}{l}\text { Innovations and } \\
\text { overlooking. }\end{array}$ & 2.85 & 1.672 & 0.864 \\
\hline & & Add value to user. & 3.29 & 1.837 & 0.832 \\
\hline \multirow{7}{*}{$\begin{array}{l}\text { Customer } \\
\text { satisfaction }\end{array}$} & \multirow{7}{*}{$\begin{array}{c}\text { K.M.O.= } 0.900 \\
\text { Bartlett's Sig = } \\
0.00 \\
(\text { TVE) }=75.389 \\
\text { Cronbach (a) } \\
=0.944\end{array}$} & I'm overall satisfied. & 2.57 & 1.449 & 0.861 \\
\hline & & $\begin{array}{l}\text { I'm pleased for } \\
\text { fulfillment of } \\
\text { expectations. }\end{array}$ & 2.80 & 1.605 & 0.876 \\
\hline & & $\begin{array}{l}\text { I'm pleased for services } \\
\text { compare with ideal. }\end{array}$ & 3.54 & 1.712 & 0.804 \\
\hline & & $\begin{array}{l}\text { I'm pleased for } \\
\text { fulfillment of personal } \\
\text { needs. }\end{array}$ & 2.54 & 1.466 & 0.865 \\
\hline & & $\begin{array}{l}\text { I'm pleased for overall } \\
\text { quality. }\end{array}$ & 2.71 & 1.474 & 0.901 \\
\hline & & $\begin{array}{l}\text { I'm pleased for service } \\
\text { quality. }\end{array}$ & 2.73 & 1.505 & 0.907 \\
\hline & & $\begin{array}{l}\text { I'm pleased for product } \\
\text { quality. }\end{array}$ & 2.74 & 1.477 & 0.859 \\
\hline
\end{tabular}

Table 1: Factor Analysis \& Reliability Analysis

According to Malhotra (1999) for factor analysis to apply: (i) the K.M.O. indicator must have values over 0.6, (ii) the significance of Bartlett's test of sphericity must be lower than 0.05 , (iii) TVE must be bigger than $60 \%$ and (iv) the loadings of every variables must be higher than 0.7 . It is easily confirmed that the examined indicators fulfil the above requirements and therefore can be used to further examine the model and test the research hypotheses. It must be stressed that for factors with two variables K.M.O.values higher than 0.5 are accepted (Malhotra, 1999).

\subsection{Reliability Analysis}

There are various ways that reliability can be evaluated (de Vellis, 1991; Carmines \& Zeller, 1979), with Cronbach alpha (a) being the most common one. According to this indicator, values bigger than 0.6 imply consistency and reliability in the way the factors were measured (Nunnally, 1978; de Vellis, 1991; Carmines \& Zeller, 1979). In the present study the values of Cronbach alpha indicator are $>0.8$, except for the factor "customer complaints" where the Cronbach indicator is 0.629 . 
International Journal of Managing Value and Supply Chains (IJMVSC) Vol. 3, No. 4, December 2012

\subsection{Structural Equation Model}

For the development of the model the stuctural equation method (Structural Equation Modeling $\eta$ SEM) was used. Confirmatory factor analysis (CFA) was used to examine whether customer satisfaction consists of all 5 factors included in the analysis. The overall model fit was evaluated using four fit measures: (i) chi-square/ degree of freedom ( $\chi^{2 / d . f .), ~(i i) ~ g o o d n e s s ~ o f ~ f i t ~ i n d e x ~}$ (GFI), (iii) comparative fit index (CFI), and (iv) root mean square error of approximation (RMSEA) (Smith and McMillan, 2001). The level of all the above indexes was within acceptable range indicating good fit of the measurement model.

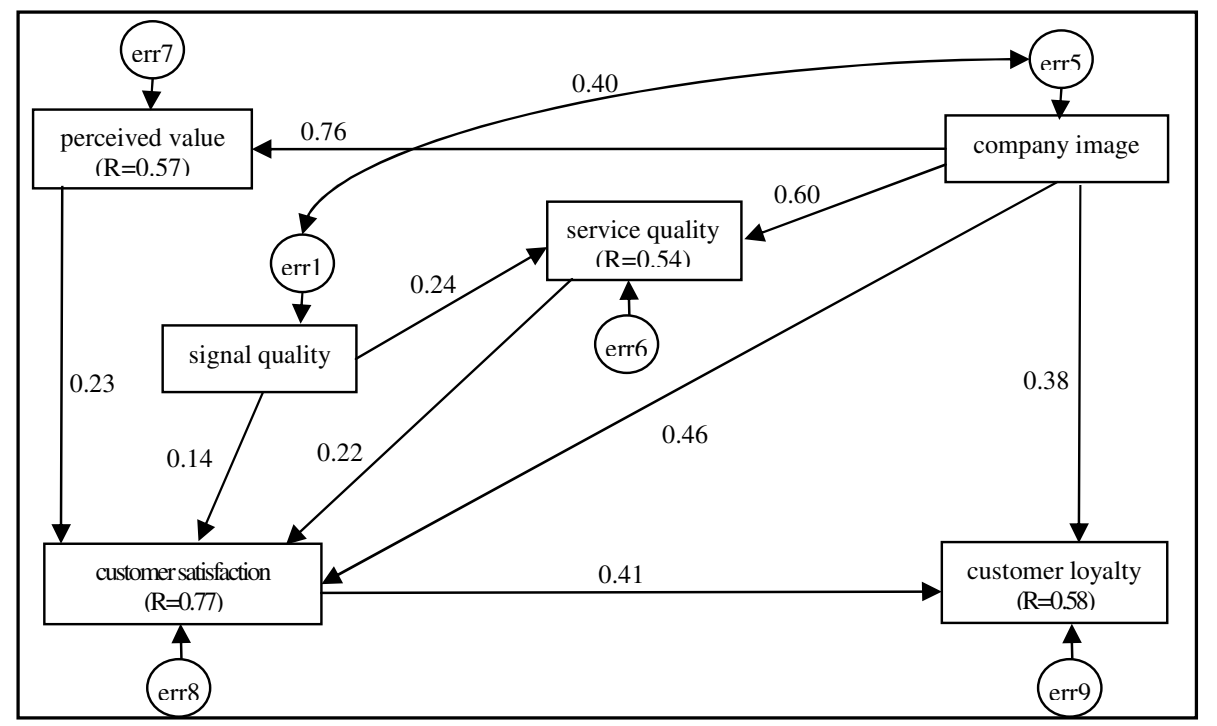

Figure 2: Research model

\begin{tabular}{|c|c|c|c|c|}
\hline CMIN/DF & CFI & GFI & TLI & RMSEA \\
\hline 5.623 & 0.981 & 0.971 & 0.944 & 0.124 \\
\hline
\end{tabular}

\begin{tabular}{|l|c|c|c|c|c|c|}
\hline Factors & \multicolumn{3}{|c|}{ Signal Quality } & \multicolumn{3}{c|}{ Perceived value } \\
\hline Effect & Direct & Indirect & Total & Direct & Indirect & Total \\
\hline $\begin{array}{l}\text { Signal } \\
\text { quality }\end{array}$ & & & & & & \\
\hline $\begin{array}{l}\text { Perceived } \\
\text { value }\end{array}$ & & & & & & \\
\hline $\begin{array}{l}\text { Service } \\
\text { quality }\end{array}$ & 0.237 & 0.078 & 0.078 & & 0.093 & 0.093 \\
\hline $\begin{array}{l}\text { Customer } \\
\text { loyalty }\end{array}$ & & & & & & \\
\hline $\begin{array}{l}\text { Company } \\
\text { image }\end{array}$ & & 0.052 & 0.189 & 0.226 & & 0.226 \\
\hline $\begin{array}{l}\text { Customer } \\
\text { satisfaction }\end{array}$ & 0.137 & & & & & \\
\hline
\end{tabular}

Table 2a: Total effects (directs and indirects)

\begin{tabular}{|l|c|c|c|c|c|c|}
\hline Factors & \multicolumn{3}{|c|}{ Service quality } & \multicolumn{3}{c|}{ Customer loyalty } \\
\hline Effect & Direct & Indirect & Total & Direct & Indirect & Total \\
\hline
\end{tabular}


International Journal of Managing Value and Supply Chains (IJMVSC) Vol. 3, No. 4, December 2012

\begin{tabular}{|l|l|l|l|l|l|l|}
\hline $\begin{array}{l}\text { Signal } \\
\text { quality }\end{array}$ & & & & & & \\
\hline $\begin{array}{l}\text { Perceived } \\
\text { value }\end{array}$ & & & & & & \\
\hline $\begin{array}{l}\text { Service } \\
\text { quality }\end{array}$ & & 0.090 & 0.090 & & & \\
\hline $\begin{array}{l}\text { Customer } \\
\text { loyalty }\end{array}$ & & & & & & \\
\hline $\begin{array}{l}\text { Company } \\
\text { image }\end{array}$ & & & 0.217 & & & \\
\hline $\begin{array}{l}\text { Customer } \\
\text { satisfaction }\end{array}$ & 0.217 & & & & \\
\hline
\end{tabular}

Table 2b: Total effects (directs and indirects)

\begin{tabular}{|l|c|c|c|c|c|c|}
\hline Factors & \multicolumn{3}{|c|}{ Company image } & \multicolumn{3}{c|}{ Customer satisfaction } \\
\hline Effect & Direct & Indirect & Total & Direct & Indirect & Total \\
\hline $\begin{array}{l}\text { Signal } \\
\text { quality }\end{array}$ & & & & & & \\
\hline $\begin{array}{l}\text { Perceived } \\
\text { value }\end{array}$ & 0.757 & & 0.757 & & & \\
\hline $\begin{array}{l}\text { Service } \\
\text { quality }\end{array}$ & 0.605 & & 0.605 & & & \\
\hline $\begin{array}{l}\text { Customer } \\
\text { loyalty }\end{array}$ & 0.384 & 0.312 & 0.697 & 0.412 & & 0.412 \\
\hline $\begin{array}{l}\text { Company } \\
\text { image }\end{array}$ & & & & & & \\
\hline $\begin{array}{l}\text { Customer } \\
\text { satisfaction }\end{array}$ & 0.457 & 0.302 & 0.759 & & & \\
\hline
\end{tabular}

Table 2c: Total effects (directs and indirects)

Direct, indirect and total effects between the factors, are presented in Table 2. The total effect of perceived value, signal quality, service quality and company image on customer satisfaction is from high to very high $(0.226,0.189,0.217$ and 0.759$)$. All of them explain about $77 \%$ of customer satisfaction.

This evidence shows how important these factors are together, and indicates that the MTS providers should pay attention to them. The total effect of customer satisfaction and company image on customer loyalty is also very high $(0.412 \kappa \alpha 10.697)$. In this case, $58 \%$ of customer loyalty is explained from the other factors. This is also an important finding which should be taken into consideration by MTS companies.

\section{CONCLUSIONS - RESEARCH LIMITATIONS}

Many and very significant conclusions are devired from this research. To begin with, the factors that were examined have a significant effect on consumers' satisfaction. Companies must consider plenty of parameters in order to succeed in their goal.

The increase in customer satisfaction leads to an increase in customer loyalty. This can lead to a decrease in the price elasticity, lower costs for future transactions, decreased costs of failure, 
lower costs for attracting new customers and an improvement in the reputation of the company (Anderson et al., 1994b).

Moreover, it is understood that the signal quality and network coverage is the factor that least affects customer satisfaction. Although the above conclusion was not expected, the explanation may be simple. When MTS first came into our lives, the signal quality was the greatest issue that concerned consumers. MTS companies did not offer network coverage in many locations and customers sought the one that would cover them the most. Nowadays, the services offered by MTS companies have been improved significantly in this respect.

As expected, it was found that the customer satisfaction affects to a great extent customer's loyalty to the company. When a customer is pleased and satisfied by the services that are offered to him, he remains a customer of the company and uses even more services from the same company. Therefore, companies are obliged to keep their customers satisfied if they want to survive in a competitive environment as the one of MTS service providers.

Finally, the most important conclusion that was drawn from the present study is that the image of the company is the factor that affects more than any other factor customer satisfaction and furthermore, affects to a great extent the customer loyalty. The most obvious interpretation is that customers are greatly affected by the "name" of the company and do not equally value other factors such as the quality of the services or the network coverage.

Through the present study, much useful information can be derived that involve the image of the Greek market in the sector of MTS. From an administrative viewpoint, acquiring the knowledge of what more people want to be offered by a company is very important. Customers of MTS providers indicated that the main issue that concerns them is the reduction in the cost of the services, thus, where substantial emphasis must be given by the providers on this issue.

This study has some limitations. The survey was carried out in a sample of 300 people. Perhaps, the survey should be repeated using a larger sample for better results.

The survey was based on a certain consumer satisfaction model. Even though useful conclusions were drawn, the inclusion of some other factors could improve the model.

Since some people from the sample, especially people of older age, are not substantially conversant with the subject but they are simple users, that may have had an impact on their answers.

Moreover, due to the fact that the questions have elements of subjectivity, some of the respondents may have overestimated a question by evaluating it with 1 (on Likert scale) when it should be 2 , or underestimated one by evaluating it with 6 when it should be 5 .

Furthermore, the present research has many parameters which presented a problem for the collection of all the data that were necessary.

Finally, people that used Q-telecom did not participate in the research, due to the fact that the company does not have a privately-owned telecommunication network.

\section{REFERENCES}

[1] Anderson, E.W. and Fornell, C. (2000), "Foundations of the American customer satisfaction index”, Journal of Total Quality Measurement, Vol. 11 No. 7, pp. 869-82.

[2] Anderson, E.W., Fornell, C. and Lehmann, D.R. (1994a), "Customer satisfaction, market share and profitability: findings from Sweden”, Journal of Marketing, Vol. 58, pp.129-41.

[3] Anderson, E.W., Fornell, C. and Lehmann, D.R. (1994b), "Customer satisfaction, market share, and profitability: findings from Sweden”, Journal of Marketing, Vol.58, pp. 53-66.

[4] Athanassopoulos, A.D. (2000), “ Customer satisfaction: cues to support market segmentation and explain switching behavior”, Journal of Business Research, Vol. 47, pp. 191-207. 
[5] Barich, H., Kotler, P., (1991). A framework for marketing image management. Sloan Management Review 32(2), 94-104.

[6] Carmines, E.G. and Zeller, R.A., (1979), "Reliability and validity assessment" Beverly Hills: Sage. H61C26.

[7] Churchill, G.A. and Surprenant, C. (1982), "An investigation into the determinants of customer satisfaction", Journal of Marketing Research, Vol. 19, November, pp. 491-504.

[8] Day, G.S. (1990), Market Driven Strategy: Processes for Creating Value, Free Press, New York, NY.

[9] de Vellis, R,F., (1991). "Scale development”, Newbury Park: Sage Publication

[10] Dichter, E., (1985). What's in an image? Journal of Consumer Marketing 2(1), 75 \}81.

[11] Dick, A.S. and Basu, K. (1994), "Customer loyalty: toward an integrated conceptual framework", Journal of the Academy of Marketing Science, Vol. 22, pp. 99-113.

[12] Engel, J.F. and R.D. Blackwell, (1982), Consumer Behavior, CA: Holt, Rinehart and Winston.

[13] Erevelles, S. and C.A. Leavitt, 1992, 'Comparison of Current Models of Consumer Satisfaction / Dissatisfaction', Journal of Consumer Satisfaction, Dissatisfactior1 and Complaining Behavior, Vol. 5, pp. 104-14.

[14] Finn, D., (1961). The price of corporate vanity. Harvard Business Review 39, 135$\} 143$.

[15] Flavian, C. and Guinaliu, M. (2006), "Consumer trust, perceived security and privacy policy: three basic elements of loyalty to a web site", Industrial Management \& Data Systems, Vol. 106 No. 5, pp. 601-20.

[16] Fornell, C., Johnson, M.D., Anderson, E.W., Cha, J. and Bryant, B.E. (1996), "The American customer satisfaction index: nature, purpose and findings", Journal of Marketing, Vol. 60, pp. 718. Vol. 22 No. 2, pp. 217-45.

[17] Fornell, C. and Westbrook, R.A., (1984). "The Vicious Circle of Consumer Complaints," Journal of Marketing, 48 (3) 68-78.

[18] Grigoroudis, E. and Siskos, Y. (2004), "A survey of customer satisfaction barometers: some results from the transportation-communications sector", European Journal of Operational Research, Vol. 152 No. 2, pp. 334-53.

[19] Gronroos, C. (1984), "A service quality model and its marketing implications", European Journal of Marketing, Vol. 18 No. 4, pp. 36 - 44.

[20] Herbig, P., Milewicz, J., Golden, J., (1994). A model of reputation building and destruction. Journal of Business Research 31, 23$\} 31$.

[21] Hunt, H.K., (1977), 'CSID - Overview and Future Research Direction', in H.K. Hunt, ed., Conceptualization and Measurement of Consumer Satisfaction and Dissatisfaction, Cambridge, MA: Marketing Science Institute.

[22] Kotler, P., (1982). Marketing for Nonprofit Organization, 2nd Edition. Prentice-Hall, Englewood Cliffs, NJ.

[23] Malhotra NK (1999). Marketing Research. An Applied Orientation. International Edition. 3rd edition Prentice Hall, London.

[24] Martensen, A., Kristensen, K. and Grønholdt, L. (2000), "Customer satisfaction measurement at post Denmark: results of application of the European customer satisfaction index methodology", Total Quality Management, Vol. 11 No. 7, pp. 1007-15.

[25] Narver, J.C. and Slater, S.F. (1990), "The effect of a market orientation on business profitability", Journal of Marketing, Vol. 54 No. 4, pp. 20-35.

[26] Nunnally, J.C. (1978). Psycometric Theory (2nd ed). New York: McGraw-Hill

[27] Oliver, R.L., (1997). Satisfaction: A Behavioral Perspective on the Consumer. McGraw-Hill, New York.

[28] Parasuraman, A., Berry, L. and Zeithaml, VV. (1991), "Perceived service quality as a customerfocused performance measure: an empirical examination of organizational barriers using and extended service quality model”, Human Resource Management, Vol. 30 No. 3, pp. 335 - 64.

[29] Parasuraman, A., Zeithmal, V.A. and Berry, L.L. (1988), "SERVQUAL: a multiple- item scale for measuring consumer perceptions of service", Journal of Retailing, Vol. 64, Spring, pp. 12 40.

[30] Rust, R.T., Zahorik, A.J., (1993). Customer satisfaction, customer retention, and market share. Journal of Retailing 69, 145-156.

[31] Smith, I., Macmillan, P., (2001). "Explaining Post-War Cinema Attendance in Great Britain," Journal of Cultural Economics, Springer, vol. 25(2), pages 91-108 
International Journal of Managing Value and Supply Chains (IJMVSC) Vol. 3, No. 4, December 2012

[32] Tse, D.K. and P.C. Wilton, (1988), 'Models of Consumer Satisfaction Formation: An Extension', Journal of Marketing Research, Vol. 25, May, pp. 204-12.

[33] Turkyilmaz A., Ozkan C. (2007), "Development of a customer satisfaction index model: An application to the Turkish mobile phone sector", Industrial Management \& Data Systems, Vol. 107 No. 5.

[34] Woo, Ka-Shing and Fock, Henry, K. Y. (1999), "Customer Satisfaction in the Hong Kong Mobile Phone Industry”, The service industries Journal, 19:3, 162 - 174.

[35] Yi, Y. (1991), “A critical review of consumer satisfaction”, in Zeithaml, V.A. (Ed.), Review of Marketing 1990, American Marketing Association, Chicago, IL, pp. 68-123. 